\title{
Photo-oxidative stress in coconut seedlings: Early events to leaf scorching and seedling death
}

\author{
Kumar S. Naresh*1 and Kasturi Bai K. V.
}

\author{
Plant Physiology and Biochemistry Section, Central Plantation Crops Research Institute \\ Kasaragod, 671 124, Kerala, India \\ ${ }^{1}$ Current address: Division of Environmental Sciences, Indian Agricultural Research Institute, PUSA, New Delhi, \\ 110012, India
}

* Corresponding author: nareshkumar.soora@gmail.com Received: 22 May 2009; Accepted: 07 November 2009.

\begin{abstract}
Experiments were conducted on coconut seedlings to delineate events of photo-oxidative stress damage. Studies on chlorophyll fluorescence indicated a clear case of excess light energy under high light conditions causing stress to coconut seedlings raised under coconut palms. Quantum yield of photo-chemistry of leaflets exposed to high light was significantly less than those under shade. Seedlings exposed to high light and then shifted to shade have shown significant improvement in quantum yield. Excess light energy harvested by chlorophyll antenna caused high non-photochemical quenching resulting in production of biologically toxic super oxide, hydrogen peroxide and hydroxyl radicals. It is apparent that photoinhibition of photosynthesis takes place due to i) PSII down regulation and ii) damage to PS II system in initial stages of exposure to excess light and under prolonged exposures inhibition is caused due to iii) chlorophyll bleaching and iv) damage to chloroplast and cell membrane integrity, followed by reduction in photosynthetically active leaf area because of scorching thus reducing canopy photosynthesis. Protein concentration in leaf tissue was higher in seedlings in high light conditions. Three distinct low molecular weight proteins with pl of 4.9, 8.4 and 10.15 having $\mathrm{M}_{\mathrm{r}}$ less than 20,000 were found in seedlings exposed to high light intensities. Results clearly demonstrate the events that take place at early stage to subsequent cascading effects leading to the scorching and death of leaf and even seedling death under severe conditions.
\end{abstract}

Key words: Cocos nucifera, chlorophyll fluorescence, oxidative stress, photosynthesis, lipid peroxidation, gas exchange, proteins

\section{INTRODUCTION}

Coconut (Cocos nucifera L.) seedlings are exposed to various stresses when they are raised in nursery as well as in field planted conditions. For better growth and for better field establishment, seedlings need to be raised under shade and nursed well. Generally, seedlings are raised in the shade of the adult palms, exposing seedlings to high light intensities during at least some time of the day. In the current experiment, the influence of high light intensity on coconut seedlings is studied.

Photoinhibition of photosynthesis, considered a natural phenomenon, is caused by high light intensities. This is related to long-term depression of quantum efficiency due to damage to photosynthetic system because of excess photosynthetic photon flux density (Demming-Adams Adams, 1992; Walters and Horton, 1993). Photosystem II is the primary target as chloroplasts are the major source of reactive oxygen forms $\left(\mathrm{H}_{2} \mathrm{O}_{2}, \mathrm{HO}^{\circ}{ }^{-}\right.$and $\mathrm{O}_{2}{ }^{\circ}{ }^{-}$in plants. These active oxygen species are produced mainly under excess light conditions (Foyer and Noctor, 2000) when the photon absorption exceeds the rate of photon utilization for the production of ATP and NADPH during light reaction in photosynthesis. Lipid peroxides and other radicals are produced via the chain reactions starting with $\mathrm{HO}^{\text {* }}$ (Halliwell and Gutteridge, 1999). When the turnover of super 
active oxygen radicals exceeds scavenging capacity, then they cause damage to cell membrane affecting the cell membrane integrity. The oxidative stress is known to cause i) chlorophyll bleaching ii) lipid peroxidation and iii) affect the enzymes due to $\mathrm{H}_{2} \mathrm{O}_{2}, \mathrm{HO}{ }^{\circ}$ - and $\mathrm{O}_{2}{ }^{\circ}$-radicals (Treves and Perl, 2002). Moreover, the turnover rate of $\mathrm{DI}$ protein in photosynthetic system declines with increase in irradiance leading to the damage of PSII reaction centre causing down regulation of photosynthesis (Arato, 2004). The chlorophyll bleaching under high light intensities is considered to be the terminal symptom of oxidative stress, and is caused by $\mathrm{H}_{2} \mathrm{O}_{2}$ or its derivative $\mathrm{HO}^{\circ}$ - (Mano, 2002). Subsequent cascading irreversible damages including oxidation of DNA and proteins, etc. cause cell death leaving scorching symptoms on leaf. The influence of high light intensity stress on coconut seedlings is not known in terms of physiological mechanism, even though the influence of water stress is well defined (Rajagopal et al., 2006; Naresh Kumar et al., 2006). A detailed experiment was conducted to study the influence of excess light on bio-physical, biochemical, physiological and morphological aspects of coconut seedling with an objective to delineate the mechanism of photo-oxidative stress-damage in coconut seedlings.

\section{MATERIALS AND METHDS}

One and half year old uniform seedlings of coconut ( $\mathrm{Cv}$. West Coast Tall-WCT) were maintained in polybag nursery in a net house. Seedlings were provided with irrigation once in four days. Polybags contained the potting mixture consisting of fertile soil, sand and farm yard manure. Three sets of WCT seedlings (12 seedlings/set) were maintained for experimental purpose. One set of seedlings were grown continuously in net house at low light intensities $\sim 350 \mu \mathrm{mol} \mathrm{m}^{-2} \mathrm{~s}^{-1}$, The second set was maintained under high light intensity (1500 $\mu \mathrm{mol} \mathrm{m} \mathrm{m}^{-2} \mathrm{~s}^{-1}$ ). The third set of seedlings was initially grown in light levels of $\sim 350 \mu \mathrm{mol} \mathrm{m} \mathrm{m}^{-2} \mathrm{~s}^{-1}$ and then was shifted to high light intensity $\left(1500 \mu \mathrm{mol} \mathrm{m}^{-2} \mathrm{~s}^{-1}\right)$ and after 15 days they were shifted back to the low light intensity $\left(350 \mu \mathrm{mol} \mathrm{m}^{-2} \mathrm{~s}^{-1}\right)$ conditions.

Seedlings were monitored on daily basis for changes in chlorophyll fluorescence, gas exchange characteristics, chlorophyll bleaching, lipid peroxidation and leaf water potentials. Data were collected on six seedlings in each set and were used for analyzing the oxidative damage to the photosynthetic system. Quantitative changes in proteins were estimated in stressed and non-stressed seedlings. Data on seedling functional leaf area were collected at frequent intervals to assess the change in leaf area using non-destructive method (Ramadasan et al., 1980) and by tracings on graph (to estimate the damaged area). Difference in leaf area from earlier measurement gave change in functional leaf area. All these analyses were done seedling-wise and for physiological and biochemical measurements, the middle leaflets of fully split-opened frond (third leaf from top) were chosen.

Chlorophyll fluorescence: Chlorophyll fluorescence was estimated using the Pulse Modulated Florescence meter (PAM-2000, Walz, Germany). Leaflets were dark adopted for about 45 min for obtaining the Fo and Fm values and then were exposed to light for recording Fo' and Fm' values. Averaged ETR, qP (photo-chemical quenching) and qN (non-photochemical quenching), Yield $(Y)$, were obtained in saturation pulse mode at field light levels and using online calculations as per Gentry et al. (1989).

Gas exchange characteristics: The gas exchange characteristics of the seedlings were recorded using the portable photosynthetic system (LICOR-6400, LICOR Inc., USA). Observations were made from 9am to $11 \mathrm{am}$ at ambient $\mathrm{CO}_{2}$ concentrations and the air flow was set to $200 \mathrm{~mL} \mathrm{~s}^{-1}$. Relative humidity and temperature of air flow into the leaf chamber were controlled during the period of measurements. Recordings were made when the $\mathrm{Ci}$ was stabilized. The PAR levels were maintained either at 350 or $1500 \mu \mathrm{mol} \mathrm{m}^{-2} \mathrm{~s}^{-1}$ as per the experimental setup. Water use efficiency (WUE) was calculated as ratio of net photosynthetic rate $(\mathrm{Pn})$ to transpiration rate $(\mathrm{E})$ and also as ratio of Pn to stomatal conductance (gs).

The leaf to air vapour pressure deficit, leaf to air temperature difference was seconde and leaf temperature was calculated online using the LiCOR-6400 software, where the leaf and air temperature along with air $\mathrm{RH}$ are considered for calculations.

Chlorophyll: The chlorophyll concentrations were estimated by grinding the fresh leaf tissue $(500 \mathrm{mg})$ in $80 \%$ acetone. The extract was filtered through Whatman No 42 in dark conditions. The optical density of the filtrate was read at 645,654 and $663 \mathrm{~nm}$ in a UV spectrophotometer (UV160A; Shimadzu, Japan) and the chlorophyll a, b and total concentrations were estimated as per Witham et al., 1971. 
Lipid peroxidation: The fresh leaflet tissue $(500 \mathrm{mg})$ was mixed with $0.1 \%$ trichloroacetic acid (TCA). After 30 min samples were centrifuged at $10,000 \mathrm{~g}$ for $5 \mathrm{~min}$. The supernatant was added to $0.1 \%$ TCA and $20 \%$ TCA containing $0.5 \%$ thiobarbutyric acid in 1:1:4 ratio. The reaction mixture was put in boiling water bath for 30 min and then reaction was stopped by placing quickly in ice bath. Samples were centrifuged for $5 \mathrm{~min}$ at $10,000 \mathrm{~g}$. Absorbance of supernatant was measured at $532 \mathrm{~nm}$ and adjusted for non-specific absorbance at $600 \mathrm{~nm}$. Reaction mixture with un-boiled extract of each sample served as the respective blank. Lipid peroxidation is expressed as (A600s-A532 $2_{\text {sample) }}$-(A600bA532 $2_{\text {blank }}$.

Leaf water potential: The leaflet water potential was measured using the Scholander pressure chamber (Skye, USA) by placing immediately after excising the leaflets.

Quantitative changes in proteins: The leaflet tissue (500mg) was frozen in liquid nitrogen immediately after excise and was homogenized in 1:4 volumes of Trisextraction buffer (Tris 50mM; NaCl $50 \mathrm{mM}$; EDTA 2mM, $\beta$-mercaptoethanol $5 \mathrm{mM}$, PMSF $1 \mathrm{mM}) 8 \mathrm{pH}$ in the presence of insoluble PVPP. The extract was centrifuged at 12,000 rpm for 10 min at $4{ }^{\circ} \mathrm{C}$ in refrigerated centrifuge (Hareus, Germany). The protein concentration in the extract was estimated following the method of Bradford, 1976 using CBB G250 dye. The OD was read at $595 \mathrm{~nm}$. The standard curved, developed using BSA, was used for the final estimations of protein concentrations.

Qualitative 2-D analysis of proteins by IEF and SDSPAGE: The leaf tissue $(500 \mathrm{mg})$, powdered in liquid nitrogen, was homoginized in chilled $\left(-20^{\circ} \mathrm{C}\right)$ acetone, TCA (10\% w/v) and $\beta$-mercaptoethanol $(0.1 \% \mathrm{v} / \mathrm{v})$ mix and kept in a deep freezer (Blue star, USA) at $-20{ }^{\circ} \mathrm{C}$ for overnight. After $12 \mathrm{~h}$ sample was centrifuged at $16,000 \mathrm{rpm}$ for $30 \mathrm{~min}$ at $4^{\circ} \mathrm{C}$. To the pellet chilled-acetone and $\beta$-mercaptoethanol $(0.1 \%)$ was added, vortexed and left suspended at $-20^{\circ} \mathrm{C}$ for 30 minutes. There after vacuum dried to get the clear pellet. To this the lysis buffer (urea $9.5 \mathrm{M}$, NP-40 4\%; $\beta$-mercaptoethanol; ampholines $2 \%$ of pH 3.5-10; 5-8 and 8-10.5 pH) was added. The mix was centrifuged at $16000 \mathrm{rpm}$ for $10 \mathrm{~min}$ at room temperature. Supernatant was aspirated and centrifuged at $10000 \mathrm{rpm}$ for $10 \mathrm{~min}$ at room temperature. The protein concentration in sample was estimated and $150 \mu \mathrm{g}$ protein was loaded on to the rod gels for iso-electric focusing (IEF).
The rod gels were prepared using gel recipe of urea $(9.17 \mathrm{M})$; NP-40 (10\%); acryl amide (30\%); ampholoines ( pH 3.5-10, 5-8 and 8-10.5), APS (10\%) and TEMED. Urea (8M) was used as the gel overlay during gel polymerization. The gel was pre-run using sample overlay at $500 \mathrm{v}$ for $30 \mathrm{~min}$ and then for $1200 \mathrm{v}$ for another $30 \mathrm{~min}$ at $15^{\circ} \mathrm{C}$. After pre-run, the sample was loaded and then electrophoresis was done for 7200 volt hours at $15^{\circ} \mathrm{C}$ using $20 \mathrm{mM} \mathrm{NaOH}$ and $0.01 \mathrm{M}$ o-phosphoric acid as upper and lower buffers, respectively. The gels were taken out from the rods and equilibrated with Lamellae buffer and SDS for 30 min before use for the SDS-PAGE second dimension run.

For the SDS-PAGE, the gel recipe consisted $3 \mathrm{M}$ tris $\mathrm{HCl}$ pH 8.8; acryl amide 30\%; SDS 10\%; APS 1.5\%; TEMED. The rod gel was placed on the SDS-PAGE gel and the agarose blocks, loaded with markers of high molecular weight (HMW) and low molecular weight (LMW), were also placed on the gel. The gel was run at $30 \mathrm{~mA}$ at $10^{\circ} \mathrm{C}$. The gels were silver stained to spot the specific proteins. The samples from nonstressed seedlings formed the control.

Statistics: Data were analyzed for statistical significance in GLM using SPSS software (SPSS v10.0).

\section{RESULTS AND DISCUSSION}

The results indicated the incidence of cascade effects on coconut seedlings when exposed to high light intensity. Since the main cause for damage due to high light intensity is oxidative stress (photo-oxidative stress), the studies on chlorophyll fluorescence indicated a clear case of excess light energy under high light conditions causing stress to seedlings. Initially, coconut seedlings did not differ much for gas exchange parameters, chlorophyll fluorescence parameters or for lipid peroxidation, leaf water potential and chlorophyll contents. They were of uniform in growth and were under similar condition at the initial stage of investigation.

The studies on photo-chemistry indicated that the quantum yield of photochemistry, which closely represents the overall quantum yield of photosynthesis, of leaflets exposed to high light was significantly less than those under shade (Figure 1A). Seedlings exposed to high light and then shifted to shade exhibited significant improvement 
in quantum yield. On the contrary, the electron transport rates (ETR) were higher in seedlings exposed to high light intensities (Figure 1C). This may be mainly due to the fact that the PAR levels were used in calculating the ETRs. Since ETRs can be comparable to $\mathrm{CO}_{2}$ assimilation or $\mathrm{O}_{2}$ evolution even with some discrepancies, the data indicates that under high light conditions, ETRs are significantly high. However, seedlings shifted back to shade showed a decline in ETRs compared to those exposed to high light conditions (Figure 1C). The results on $q \mathrm{P}$ and $\mathrm{qN}$ (Figure $1 \mathrm{~A}$ and $\mathrm{B}$ ) clearly indicated that under exposed conditions, the photochemical quenching is significantly lower than under shade conditions. Significantly higher non- photochemical quenching (Figure $1 \mathrm{~B}$ ) in leaflets of seedlings exposed to high light intensities clearly demonstrate the availability of excess light energy under high light conditions, leading to the production of super oxide and oxygen radicals. The seedlings under high light were able to recover when shifted back to shade. Oxidative stress and damage to PSII reaction centers led to a decline in the quantum yield and the $\mathrm{Fv} / \mathrm{Fm}$ ratio (Figure 2) is a useful parameter of PSII photoinhibitory damage in higher plants (Bjorkman and Demming, 1987). The Fv/Fm ratios indicated that the seedlings under high light intensity are facing stress situation.
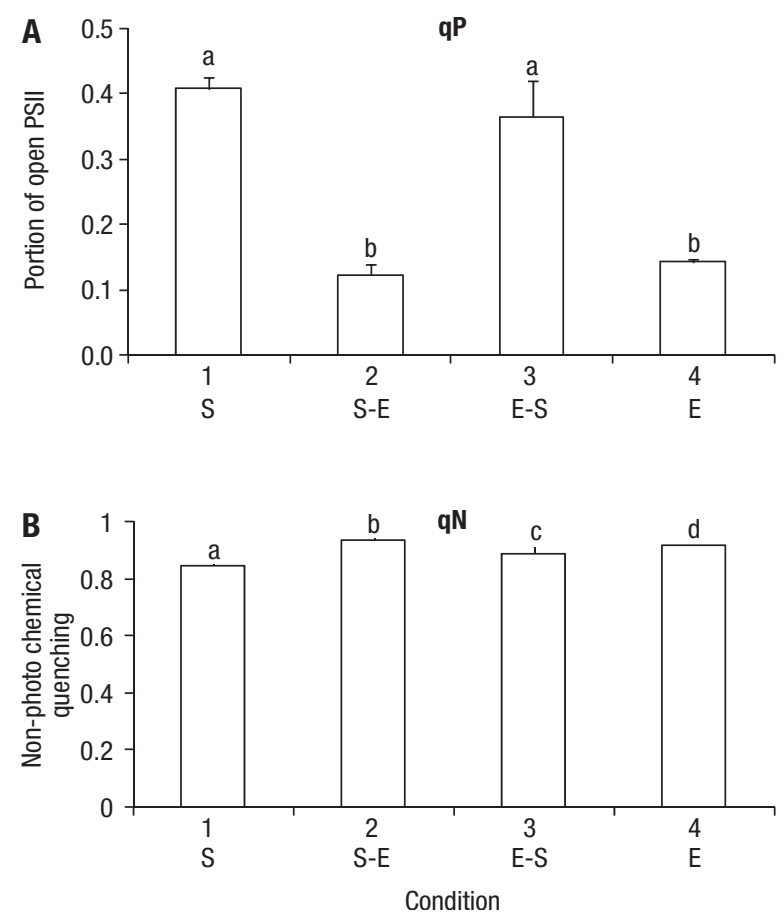
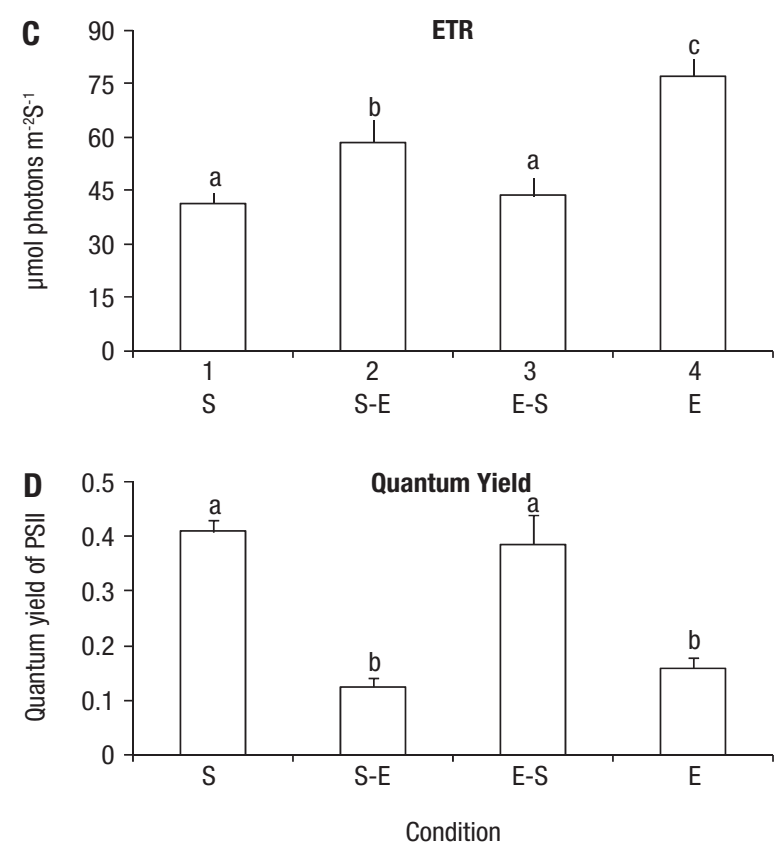

Figure 1. Chlorophyll fluorescence characteristics of leaflet under different light conditions. a) qP - photochemical quenching; b) qN - non-photochemical quenching) c) ETR-electron transport rate ( $\mu \mathrm{mol}$ photons $\mathrm{m}^{-2} \mathrm{~s}^{-1}$ ) and d) quantum yield; Bars with different alphabets are statistically varying. S- seedlings in continuous shade; S-E- seedlings in shade shifted to high light intensity conditions; E-S- seedlings exposed to high light intensity were shifted to shade conditions; E - seedlings under continuous exposure to high light intensities.

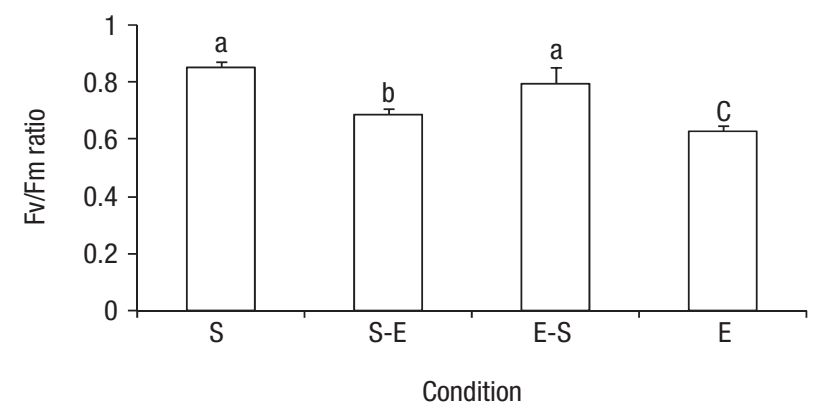

Figure 2. Fv/Fm of leaflet under different light conditions. Bars with different alphabets are statistically varying. S- seedlings in continuous shade; S-Eseedlings in shade shifted to high light intensity conditions; shade-S- seedlings exposed to high light intensity were shifted to shade conditions; $\mathrm{E}$ - seedlings under continuous exposure to high light intensities.

The available excess energy presumably led to the production of super oxide and hydroxyl radicals which caused damage to the membranes of organelles and cells as demonstrated by the results from lipid peroxide estimation. Lipid peroxidation is considered to be the criterion to monitor 
damage caused by increased reactive oxygen species (Halliwell, 1991). The results indicated that the membrane lipid peroxidation took place at double the rate in seedlings exposed to high light intensities as compared to those under shade (Figure 5). The seedlings shifted back to shade conditions shown to recover as indicated by decline in lipid peroxidation levels close to those under shade. The results clearly indicate that excess light energy caused damage to membranes of organelles and cells. The rate of lipid peroxidation was at exponential rate in initial stages of exposure i.e. up to $4^{\text {th }}$ day and the showed a steady state of two- to two and
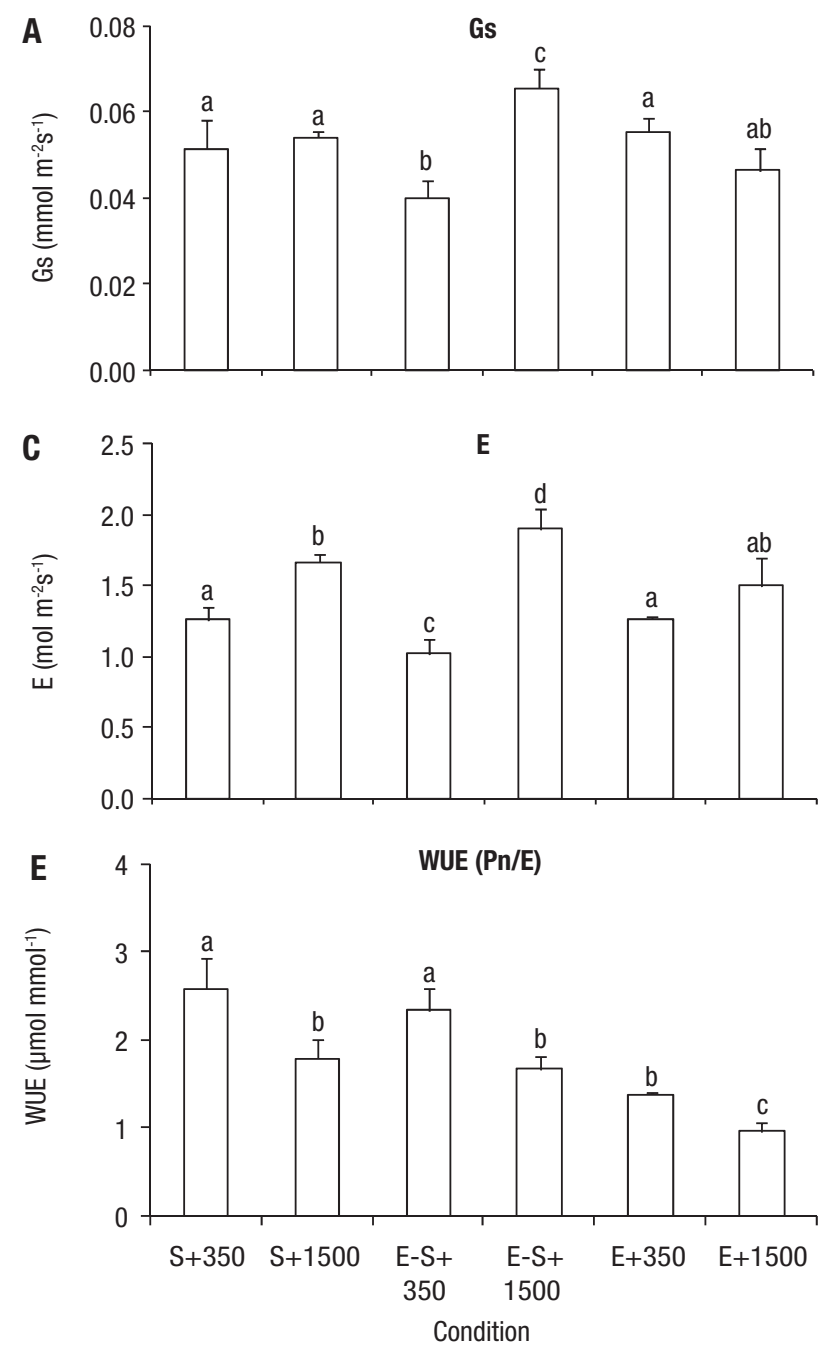

half fold higher peroxidation than in unexposed seedlings. Damage to chloroplast integrity can be assessed from the chlorophyll beaching in seedlings exposed to high light intensities. Seedlings shown to recover once they are shifted to shade. Total chlorophyll and chlorophyll a and b contents were significantly lower in exposed seedlings (Table 1). The chlorophyll a seems to be more susceptible to photo-damage as indicated from lower chl. $\mathrm{a} / \mathrm{b}$ ratios in exposed seedlings. High light conditions may either not favour the synthesis of chlorophyll or may favor rapid degradation of the pigments as was observed earlier by Jiao et al., 2003.
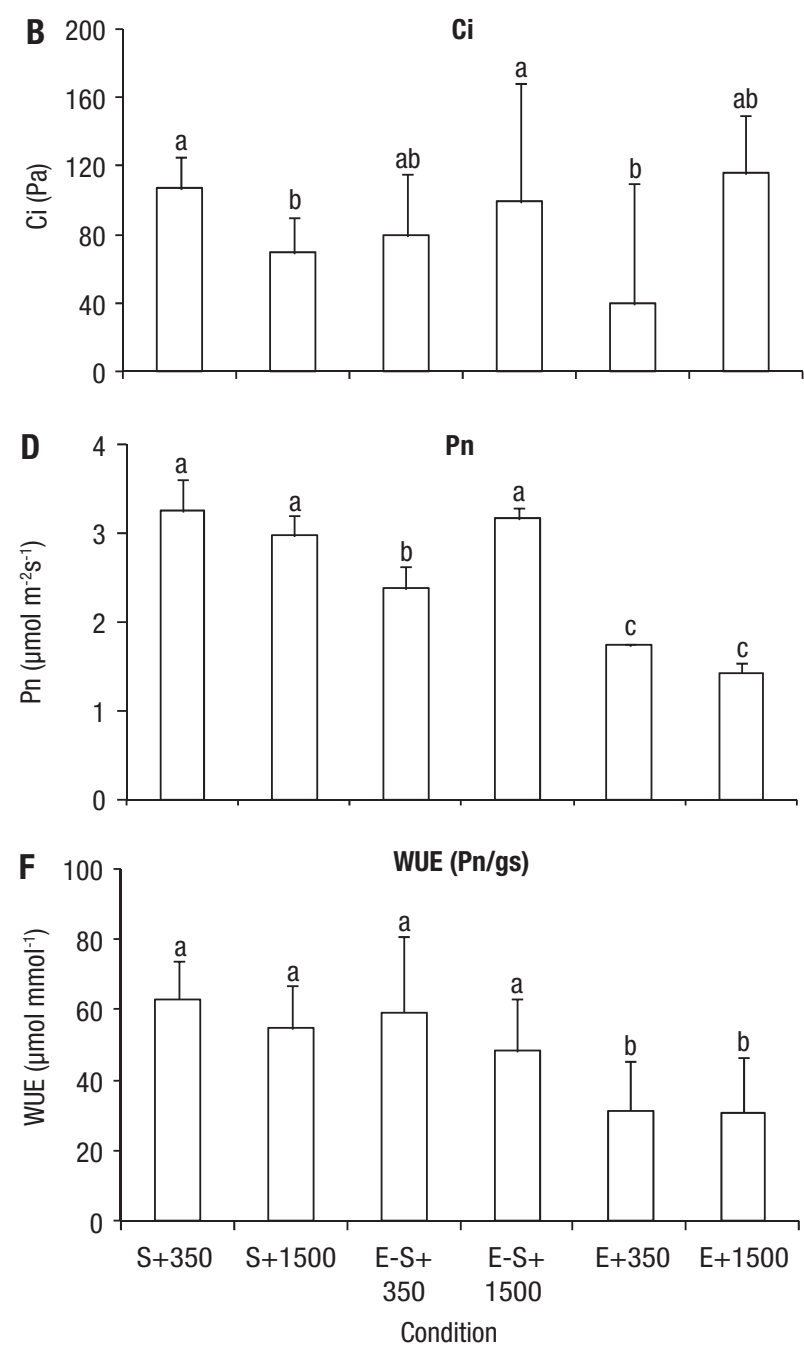

Figure. 3. Gas exchange and water use efficiency characteristics of leaflet under different light conditions. $\mathrm{A}$, Gs - stomatal conductance; $\mathrm{B}$, Ci- internal $\mathrm{CO}_{2}$ concentration; C, E- transpiration rate; D, Pn-net photosynthetic rate; $E$, WUE-(Pn/E) instantaneous water use efficiency and F, WUE (Pn/Gs)- intrinsic water use efficiency. Bars with different alphabets are statistically varying. $S+350$ - seedlings in shade with $350 \mu \mathrm{mol} \mathrm{m}^{-2} \mathrm{~s}^{-1}$ PAR levels; $S+1500$ - seedlings in shade with 1500 $\mu \mathrm{mol} \mathrm{m} \mathrm{m}^{-1} \mathrm{~s}^{-1}$ PAR levels; E-S +350- Exposed seedlings brought in to shade with $350 \mu \mathrm{mol} \mathrm{m} \mathrm{m}^{-2} \mathrm{~s}^{-1}$ PAR levels; E-S +1500 - Exposed seedlings brought in to shade with $1500 \mu \mathrm{mol} \mathrm{m} \mathrm{m}^{-1} \mathrm{~s}^{-1}$ PAR levels; E+350- Exposed seedlings with $350 \mu \mathrm{mol} \mathrm{m}{ }^{-2} \mathrm{~s}^{-1}$ PAR levels; E-S +1500- Exposed seedlings with $1500 \mu \mathrm{mol} \mathrm{m} \mathrm{m}^{-2} \mathrm{~s}^{-1}$ PAR levels. 
The cascading effect of excess light energy driven damage has thus reduced the photosynthetic rates in seedlings under high light intensities (Figure 3). The stomatal conductance of leaves exposed to continuous high light have shown reduced gs mainly due to the increased VPD (Figure 4), even through all seedlings were supplied with adequate quantities of water. Closure of stomata under these conditions led to decrease in transpiration rates and resulted in increased leaf temperatures due to less thermo-regulation of leaf. Consequently, leaf temperature also built up and leaf to air temperature differences have gone up. All these led to lower the photosynthetic rates. Building up of internal $\mathrm{CO}_{2}$ concentrations indicate mesophyll limitation in exposed seedlings. While in the first place it is the photo inhibition which reduced the Pn rates in exposed seedlings. This possibly followed by the stomatal limitation and mesophyll limitation of the photosynthesis.
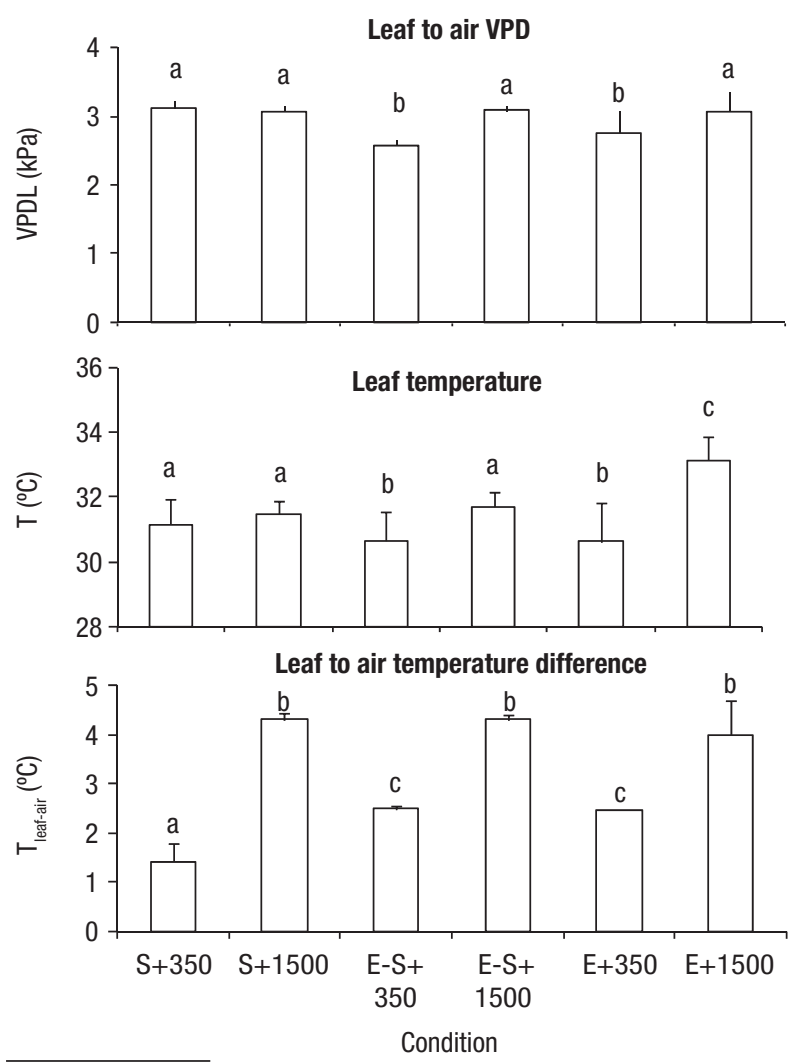

Figure 4. Microclimatic conditions of leaflet under different light conditions. Bars with different alphabets are statistically varying. $X$ axis legend details as per Figure 3 .

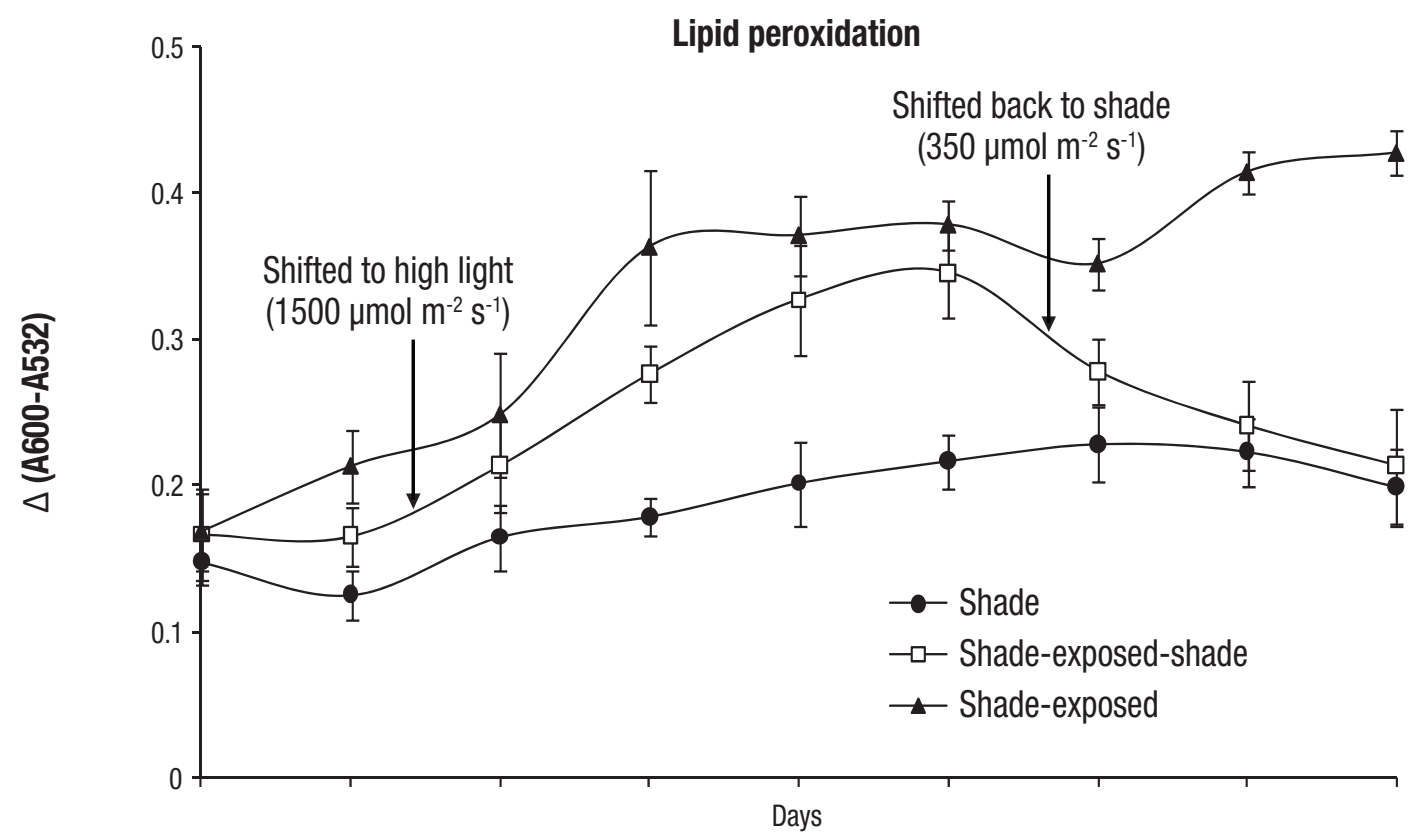

Figure 5. Lipid peroxidation of leaflet under different light conditions. One set of seedlings were maintained either in continuous shade at $350 \mu \mathrm{molm} \mathrm{m}^{-2} \mathrm{~s}^{-1}(\mathrm{Shade}) ; 2^{\text {nd }}$ set of seedlings were shifted from shade $\left(350 \mu \mathrm{molm}^{-2} \mathrm{~s}^{-1}\right)$ to exposed $\left(1500 \mu \mathrm{mol} \mathrm{m}^{-2} \mathrm{~s}^{-1}\right)$ for 15 days and then shifted back to shade (Shade-exposed-shade); and $3^{\text {rd }}$ set of seedlings were shifted from shade $\left(350 \mu \mathrm{molm}^{-2} \mathrm{~s}^{-1}\right)$ to exposed $\left(1500 \mu \mathrm{mol} \mathrm{m}^{-2} \mathrm{~s}^{-1}\right)$ levels (Shade-exposed). 
Seedlings under shade, when exposed to high light intensities while measuring Pn rates, showed increased leaf temperature. The leaf to air temperature difference was also equal to that under exposed conditions. On the contrary, leaves of exposed seedlings showed reduction in leaf temperature and leaf to air temperature differences when they were subjected to low light intensities. These demonstrate that the leaf temperature changes are predominantly light driven.

Table 1. Physiological and biochemical characteristics of leaflet under different light conditions. One set of seedlings were maintained in continuous shade at 350 $\mu$ molm ${ }^{-2} \mathrm{~s}^{-1}$ (Shade); $2^{\text {nd }}$ set of seedlings were shifted from shade $\left(350 \mu \mathrm{molm}^{-2} \mathrm{~s}^{-1}\right)$ to exposed (1500 $\left.\mu \mathrm{mol} \mathrm{m}^{-2} \mathrm{~s}^{-1}\right)$ for 15 days and then shifted back to shade (Shade-exposed-shade); and $3^{\text {rd }}$ set of seedlings were shifted from shade (350 $\left.\mu \mathrm{molm}^{-2} \mathrm{~s}^{-1}\right)$ to exposed (1500 $\left.\mu \mathrm{mol} \mathrm{m}^{-2} \mathrm{~s}^{-1}\right)$ levels (Shade-exposed). FW- fresh weight; DW- dry weight.

\begin{tabular}{|c|c|c|c|c|c|}
\hline \multirow[b]{2}{*}{ Parameter } & & \multicolumn{3}{|c|}{ Condition } & \multirow[b]{2}{*}{$C D$ at $P=0.05$} \\
\hline & & Shade & $\begin{array}{c}\text { Shade-Exposed- } \\
\text { Shade }\end{array}$ & Shade-Exposed & \\
\hline \multirow[t]{2}{*}{ Specific leaf weight } & $\mathrm{FW}\left(\mathrm{mg} . \mathrm{cm}^{-2}\right)$ & 20.57 & 20.03 & 20.91 & NS \\
\hline & DW $\left(\mathrm{mg} \cdot \mathrm{cm}^{-2}\right)$ & 6.77 & 6.69 & 7.84 & 0.23 \\
\hline Water content in tissue (\%) & & 67.07 & 66.66 & 62.39 & 2.33 \\
\hline Leaf water potential (bars) & & -8.02 & -9.91 & -10.67 & 1.2 \\
\hline Chlorophyll components & Chl a & 1.00 & 0.91 & 0.58 & 0.11 \\
\hline \multirow[t]{8}{*}{$\left(\mathrm{mg} \cdot \mathrm{g}^{-1} \mathrm{FW}\right)$} & Chl b & 0.43 & 0.36 & 0.27 & 0.08 \\
\hline & Total Chl & 1.43 & 1.26 & 0.85 & 0.14 \\
\hline & $\mathrm{Chl} \mathrm{a} / \mathrm{b}$ ratio & 2.54 & 2.31 & 2.12 & 0.09 \\
\hline & Change over shade (\%) & & & & \\
\hline & Chl a & & -9.5 & -42.2 & 5.21 \\
\hline & $\mathrm{Chl} \mathrm{b}$ & & -17.0 & -36.3 & 4.31 \\
\hline & Total Chl. & & -11.82 & -40.30 & 4.02 \\
\hline & $\mathrm{Chl} \mathrm{a} / \mathrm{b}$ ratio & & -8.9 & -16.5 & 3.22 \\
\hline \multirow[t]{2}{*}{ Leaf proteins (mg.g ${ }^{-1} \mathrm{FW}$ ) } & & 9.45 & 10.9 & 12.4 & 0.52 \\
\hline & Increase over shade (\%) & & 15.34 & 31.22 & 5.32 \\
\hline \multirow[t]{2}{*}{ Functional leaf area $\left(\mathrm{m}^{2}\right)$} & & 2.02 & 1.59 & 0.96 & 0.31 \\
\hline & Decrease over shade (\%) & & -21.29 & -52.48 & 10.6 \\
\hline \multirow[t]{2}{*}{ Rate of degradation of leaf area $\mathrm{m}^{2}$. month $^{-1}$} & & 0.25 & 0.75 & 1.20 & 0.16 \\
\hline & Increase over shade (\%) & & 200.0 & 380.0 & 56.0 \\
\hline
\end{tabular}

Seedlings under shade had significantly higher Pn rates compare to those in exposed conditions. Seedlings when shifted back to shade recovered and had higher Pn rates may be due to recovery in chlorophyll synthesis and reduced lipid peroxidation. However, their photosynthetic rates were still lower than in seedlings grown continuously under shade (Figure 3). Interestingly, in shaded seedlings the $\mathrm{Pn}$ rates declined at high light intensities. Whereas, the exposed seedlings when shifted back to shade had higher Pn rates under high light intensities. The seedlings which were continuously exposed to high light did not show any difference in Pn rates at low or high light intensities and these rates were significantly low. Consequent to the above results, the WUE of shaded seedlings is significantly higher than in exposed seedlings of all categories. These indicate that i) high light intensities for short duration promote $\mathrm{Pn}$ rates as can be seen under sun flacks in a canopy situation ii) continuous exposure to high light intensities cause damage to photosynthetic system which can not be repaired in short time, and iii) if the plants are provided shade or low light conditions for more than 2 to 3 days, then seedlings show recovery. 
Similar observations were made in the leaflets exposed to high $\left(1500 \mu \mathrm{mol} \mathrm{m}^{-2} \mathrm{~s}^{-1}\right)$ and low $\left(350 \mu \mathrm{mol} \mathrm{m}^{-2} \mathrm{~s}^{-1}\right)$ PPFD in the same leaf (Table 2). However, in this case the leaflets were like under sunflacks situation prolonged enough so that plants gave response to high light intensities. Thus these leaflets did not get damaged as in earlier case mainly due to adequate scavenging of the excess light energy and with water-water cycle operating properly (Asada et al., 1998). The Photoinhibition of photosynthesis was viewed as a process of stress-induced damage to the Photosystem II as a consequence of degredation of D1 protein in PSIl reaction centre (Kyle et al., 1984; Prasil et al., 1992; Rintamaki et al., 1995). However, recent reports suggest that, initial photoinhibition is due to formation of photochemically inactive PSII centres, which convert the excitation energy into heat and this down regulation of PSII and thermal dissipation is considered as a protective mechanism against high irradiance stress (Cleland et al. 1986; Aro et al., 1993; Gilmore and Bjorkman, 1994).

Table 2. Chlorophyll fluorescence, gas exchange and micro-climate parameters of leaflets of same frond under different light conditions. Shade- ETR-electron transport rate; qP- photochemical quenching; qN- non-photochemical quenching; Pn- net photosynthetic rate; Gs - stomatal conductance; Ci- internal carbon di oxide concentration; $\mathrm{E}$ - transpiration rate; $\mathrm{Pn} / \mathrm{E}$ - physiological water use efficiency; $\mathrm{Pn} / \mathrm{gs}$ - intrinsic water use efficiency; PAR- photosynthetically active radiation; VPDL- Leaf to air vapour pressure difference; $\Delta \mathrm{T}$ - leaf to air temperature difference.

\begin{tabular}{|c|c|c|c|c|}
\hline \multirow{2}{*}{ Parameter } & & \multicolumn{2}{|c|}{ Condition } & \multirow{2}{*}{$C D$ at $P=0.05$} \\
\hline & & Shade & Exposed & \\
\hline \multirow[t]{4}{*}{ Chlorophyll fluorescence } & Quantum Yield & 0.46 & 0.15 & 0.06 \\
\hline & ETR & 24.37 & 79.11 & 12.3 \\
\hline & $q P$ & 0.42 & 0.15 & 0.92 \\
\hline & $\mathrm{qN}$ & 0.86 & 0.94 & 0.03 \\
\hline \multirow[t]{6}{*}{ Gas exchange } & $\operatorname{Pn}\left(\mu \mathrm{mol} \mathrm{m} \mathrm{m}^{-2} \mathrm{~s}^{-1}\right)$ & 3.42 & 1.21 & 0.42 \\
\hline & Gs $\left(\mathrm{mol} \mathrm{m}^{-2} \mathrm{~s}^{-1}\right)$ & 0.05 & 0.06 & NS \\
\hline & $\mathrm{Ci}(\mathrm{Pa})$ & 106 & 185 & 23.2 \\
\hline & $\mathrm{E}\left(\mathrm{mmol} \mathrm{m} \mathrm{m}^{-2} \mathrm{~s}^{-1}\right)$ & 1.42 & 2.23 & 0.26 \\
\hline & WUE $(\mathrm{Pn} / \mathrm{E})\left(\mu \mathrm{mol} \mathrm{CO}{ }_{2} \mathrm{~mol}^{-1} \mathrm{H}_{2} \mathrm{O}\right)$ & 2.13 & 1.07 & 0.29 \\
\hline & WUE (Pn/gs) $\left(\mu \mathrm{mol} \mathrm{CO} \mathrm{mol}^{-1} \mathrm{H}_{2} \mathrm{O}\right)$ & 75.4 & 45.3 & 14.6 \\
\hline \multirow[t]{4}{*}{ Micro-climatic } & $\operatorname{PAR}\left(\mu \mathrm{mol} \mathrm{m} \mathrm{m}^{-2} \mathrm{~s}^{-1}\right)$ & 350 & 1300 & - \\
\hline & VPDL (kPa) & 2.41 & 2.78 & 0.11 \\
\hline & $\mathrm{T}_{\text {leaf }}\left({ }^{\circ} \mathrm{C}\right)$ & 31.15 & 34.87 & 0.59 \\
\hline & $\Delta \mathrm{T}=$ leaf-air $\left({ }^{\circ} \mathrm{C}\right)$ & 2.962 & 4.652 & 0.35 \\
\hline
\end{tabular}

In this experiment, it is apparent that the photoinhibition of photosynthesis takes place at i) PSIl down regulation ii) damage to PS II system in initial stages of light exposure, and under prolonged exposures this inhibition is caused due to iii) chlorophyll bleaching iv) damage to chloroplast and cell membrane integrity. This followed by the reduction leaf photosynthetically active leaf area (Table 1) due to leaf scorching thus reducing the canopy photosynthesis.

Quantitative analysis of leaf proteins indicated that the protein concentration in leaf tissue was higher in seedlings under exposed conditions, compared to those in shaded and shifted to shade (Table 1). This may be is mainly because of the reduced water contentand water potentials of the seedlings under exposed conditions. Qualitative 2-D analysis of proteins by IEF and SDSPAGE revealed three distinct LMW proteins in seedlings exposed to high light intensities. These three LMW proteins have pl of 4.9, 8.4 and 10.15 with decreasing order of relative molecular mass $\mathrm{M}_{\mathrm{r}}$ less than 20,000. In plants, reactive oxygen species -induced genes have been identified for proteins like kinase (Desikan et al., 2000) annexin (Moseyko et al., 2002) and peroxisome biogenesis (Desikan et al., 2000), among others. Changes in expression levels of 175 genes were recorded in $\mathrm{H}_{2} \mathrm{O}_{2}$ exposed Arabidopsis cells (Desikan et al., 2001).

These results indicate the cascading effects of photooxidative stress in seedlings grown under high light intensities (Figure 6). The excess light energy harvested by the chlorophyll 
antenna caused high non-photochemical quenching resulting in production of biologically toxic super oxide $\left(\mathrm{O}_{2}{ }^{-}\right)$, hydrogen peroxide $\left(\mathrm{H}_{2} \mathrm{O}_{2}\right)$ and hydroxyl $\left(\mathrm{OH}^{-}\right)$radicals, which damaged the cell membrane integrity as indicated by the increased lipid peroxidation and chlorophyll bleaching when exposed to high light intensities leading to leaf scorching. This resulted in reduced functional leaf area (Table 1) and under prolonged exposure conditions in seedling death. As summarized in Fig. 6. these results clearly demonstrate the events that take place at early stage to subsequent cascading effects leading to the seedling death under severe conditions. Apparently these effects might be revealed earlier if coupled with water stress conditions. Thus coconut seedlings behave as shade loving plants at seedling stage.

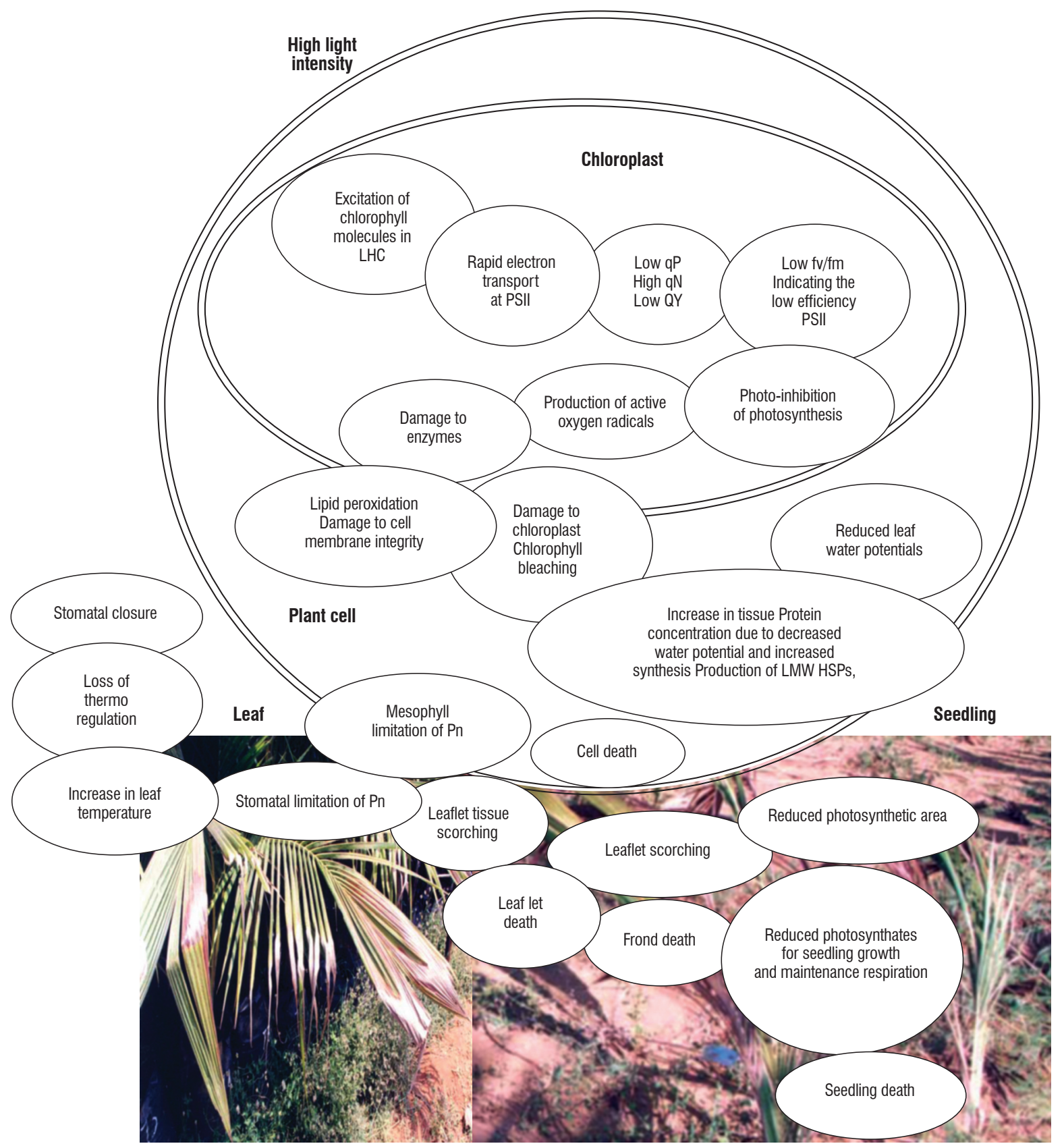

Figure 6. Cascading mechanism of photo-oxidative stress in coconut seedlings: Early events to seedling death. 
Acknowledgements: Authors are thankful to the Dr. K.U.K. Nampoothiri former Director of CPCRI, Kasaragod for their encouragement and support for the study. The help rendered by Mr. John George (T.O.), Mr. Keeran (JTO), Late Mrs. Mohinibai (lab assistant), Mr. Pramod (Lab attender), A. Balakrishnan (SRF) and Siju T. Thomas (SRF) are gratefully acknowledged.

\section{REFERENCES}

Arato A, Bondarava N, Liszkay AK (2004) Production of reactive oxygen species in chloride and calcium e- depleted Photosystem $\|$ and their involvement in Photoinhibition. Biochem. Biophy. Acta 1608:171-180.

Aro EM., Virgin I, Andersson B (1993) Photoinhibition of Photosystem II: Inactivation, protein damage and turnover. Biochem. Biophy. Acta 1143:113134.

Asada K, Endo T, Mano J, Miyake C (1998) Molecular mechanism for relaxation of and protection from light stress. In: Murata N, Satoh K (eds), Stress Responses of Photosynthetic Organisms, pp 37-52, Elsevier, Amstredam.

Bjorkman O, Demming B (1987) Photon yield of $\mathrm{O}_{2}$ evolution and chlorophyll fluorescence characteristics at $77 \mathrm{~K}$ among vascular plants of diverse origins. Planta 170:489-504.

Bradford MM (1976) A rapid and sensitive method for quantification of microgram quantities utilizing the principle of protein-dye binding. Anal. Biochem.72:248-254.

Cleland RE, Melis A, Neale PJ (1986) Mechanism of Photoinhibition: Photochemical reaction centre inactivation in system II of chloroplasts. Photosynth. Res. 9:79-88.

Demming-Adams B, Adams WW (1992) Photoprotection and other responses of plants to high light stress. Ann. Rev. Plant Physiol. Plant Mol. Biol. 43:599626.

Desikan R, Mackerness AH, Hancock JT, Neill SJ (2001) Regulation of the Arabidopsis transcriptome by oxidative stress. Plant Physiol. 127:159-172.

Desikan R, Neill SJ, Hancock JT (2000) Hydrogen peroxide-induced gene expression in Arabidopsis thaliana. Free Radical Biol. Medicine 28:773-778.

Foyer CH, Noctor G (2000) Oxygen processing in photosynthesis: regulation and signaling. New Phytol. 146:359-388.

Gilmore AM, Bjorkman 0 (1994). Adenine nucleotides and the xanthophylls cycle in leaves. II. Comparison of the effects of $\mathrm{CO}_{2}$ and temperature limited photosynthesis on Photosystem II fluorescence quenching, the adenylate energy charge and violoxanthin de-epoxidation in cotton. Planta 192:537544.

Halliwell B (1991). Reactive oxygen species in living systems. J. Medicine 91:14-19.

Halliwell B, Gutteridge JMC (1999) Free Radicals in Biology and Medicine, $3^{\text {rd }}$ ed., Oxford University Press, Oxford.

Jiao D, Ji B, Li X (2003) Characteristics of chlorophyll fluorescence and membrane lipid peroxidation during senescence of flag leaf in different cultivars of rice. Photosynth. 41:151-156.

Kyle DJ, Kuang TY, Watson JL, Arntzen CJ (1984) Movement of sub-population of the light harvesting complex (LHCII) from grana to stroma lamellae as a consequence of its phosphorylation. Biochem. Biophy. Acta 765:89-96.

Mano J (2002) Early events in Environmental Stresses in Plants - Induction Mechanisms of Oxidative Stress. In: Inz'e D, Van Montagu M (eds), Oxidative Stress in Plants, pp. 217-245. Taylor \& Francis Publishers, New York.

Moseyko N, Nhu T, Chang HS, Wang X, Feldman LJ (2002) Transcription profiling of the early gravitropic response in Arabidopsis using high density oligonucleotide probe microarrays. Plant Physiol. 130:720-728.

Naresh Kumar S, Rajagopal V, Kasturi Bai KV (2006) Adaptive strategies of coconut palm under stressful conditions. In: Hemantharanjan A (ed) Advances in Plant Physiology, Vol. 9, pp.: 155-167, Scientific Publishers (India), Jodhpur, India.

Prasil O, Adir N, Ohad I (1992) Dynamics of Photosystem II: mechanism of Photoinhibition and recovery processes. In: Barber J (Ed.), The photosystems: Structure, function and molecular biology, pp 250-348, Elsevier, New York.

Rajagopal V, Kasturi Bai KV, Naresh Kumar S (2005) Breeding for Drought Tolerance in Coconut: Status and Potentials, In: Batugal PV, Ramanatha Rao, Oliver J (eds), Coconut Genetic Resources, pp. 282-301, IPGRI publication, IPGRI-Regional Office for Asia, The Pacific and Oceania (IPGRI-APO), Serdang, Selangor DE, Malaysia.

Ramadasan A, Satheesan KV, Balakrishnan R (1980) Leaf area and shoot dry weight in coconut seedling selection. Ind. J. Agril. Sci. 50: 553-554.

Rintamaki E, Salo R, Lehtonen E, Aro EM (1995) Regulation of DI protein degradation during Photoinhibition of photosystem II in vivo: Phosphorylation of DI protein in various plant groups. Planta 195: 379-386.

Treves RP, Perl A (2002) Oxidative stress: Introduction, In: Inze D, Van Montagu M (eds), In: Oxidative Stress in Plants, pp1-32. Taylor \& Francis Publishers, New York.

Walters RG, Horton P (1993). Theoretical assessment of alternative mechanisms of non-photochemical quenching of PSII fluorescence in barley leaves. Photosynth. Res. 36: 119-139.

Witham FH, Blaydes DF, Devlin RM (1971) Experiments in Plant Physiology, Van Nostrand, New York. 